www.czasopisma.marszalek.com.pl/pl/10-15804/npw

\author{
Monika Paliszewska-Mojsiuk \\ Uniwersytet Gdański \\ ORCID ID: https://orcid.org/0000-0003-4041-821X
}

\title{
Spacer po dziejach Zakazanego Miasta
}

[recenzja książki Historia Zakazanego Miasta]

History of The Forbidden City

[book review Historia Zakazanego Miasta]

История запрещенного города

[рецензия книги Historia Zakazanego Miasta]

Tiążka pt. Historia Zakazanego Miasta ukazała się nakładem wydaw_nictwa Time Marszałek Group w 2017 r. Jest to jedna z dziewięciu części serii zatytułowanej „Historia chińskiej cywilizacji”, która przybliża czytelnikom najistotniejsze informacje dotyczące zarówno historii Państwa Środka, monumentalnych zabytków, jak i elementów szeroko rozumianej kultury. Opracowanie zostało przygotowane przez chińskiego autora, Feng Hejun, natomiast na język polski zostało ono przetłumaczone $\mathrm{z}$ języka rosyjskiego.

„Historia Zakazanego Miasta” jest podręcznym kompendium wiedzy o historii i współczesności byłego Pałacu Cesarskiego. Nie brakuje również różnorodnych ciekawostek związanych z tym miejscem. Publikacja jest dosyć krótka, ale na swoich 68 stronach przybliża czytelnikowi losy Zakazanego Miasta. Książka podzielona jest na sześć rozdziałów, które opisują okres od rozpoczęcia budowy, aż po dziś dzień, kiedy były Pałac Cesarski służy za muzeum. Zakończona jest tabelą ukazującą chronologię dynastii panujących 
w Państwie Środka oraz okresy Republiki Chińskiej i Chińskiej Republiki Ludowej.

Pierwszy rozdział zatytułowany „Powstanie Zakazanego Purpurowego Miasta” poświęcony jest czasom za panowania dynastii Ming, która wybudowała nową stolicę w Pekinie, a w nim Pałac Cesarski, w którym przez pięć stuleci mieszkali cesarze dwóch dynastii - Ming i Qing. W tej części opisane zostały etapy budowy od jej rozpoczęcia w 1407 r., przez przebudowy w latach 1421, 1557 i 1597, kiedy pałac został zniszczony przez pożary, aż do 1621 r., gdy przy kolejnej przebudowie zmieniono materiały budowlane wykorzystane przy konstrukcji. Czytelnik znajdzie w tym rozdziale również ciekawostki technologiczne związane $\mathrm{z}$ budową oraz wspomnienia o sławnych współtwórcach Zakazanego Miasta.

Rozdziały drugi oraz trzeci poświęcone są chińskiej architekturze oraz najbardziej znanym obiektom, które można znaleźć w muzeum Gugong. Głównymi zamysłami, którymi kierowano się przy budowie były koncepcja yin i yang (dwie przeciwne, lecz uzupełniające się siły), symetria oraz oś centralna. Całe miasto Pekin było planowane w stosunku do centralnego punktu, którym było Zakazane Miasto, gdyż cesarz musiał żyć w środkowym punkcie stolicy. Opisane są również najciekawsze według autora miejsca i obiekty pałacu, takie jak teatr, biblioteka czy Mur Dziewięciu Smoków.

Czwarty rozdział, zatytułowany „Historia Zakazanego Purpurowego Miasta”, poświęcony jest zdumiewającym, i - według autora - najciekawszym wydarzeniom, które miały swoje miejsce w pałacowych komnatach za czasów panowania dynastii Ming oraz Qing. Opisane są zarówno zamachy, jak i procedury wyboru następcy tronu czy pełen knowań okres panowania cesarzowej Cixi.

Dwa ostatnie rozdziały książki, piąty oraz szósty, opisują już bardziej współczesną historię Zakazanego Miasta. Począwszy od abdykacji cesarza Puyi w 1912 r., poprzez utworzenie muzeum Gugong w 1925 r., aż po dzień dzisiejszy podane są informacje o najciekawszych eksponatach do zobaczenia w byłym Pałacu Cesarskim oraz w muzeach Gugong, które znajdują się w Shenyang oraz w Tajpej.

Jak wspomniałam na początku recenzji książka ta oryginalnie została napisana w języku chińskim, a na język polski została przetłumaczona z języka rosyjskiego, w związku z tym zachwiana jest pewna płynność czytania. Dla 
osoby znającej język chiński zauważalna jest zachowana chińska stylistyka pisania, która w procesie tłumaczenia nie została przystosowana do polskiego odbiorcy. Brakuje również wstępu, określającego która transkrypcja chińskich nazw wykorzystana jest w publikacji. Niektóre nazwy własne zapisane są $\mathrm{w}$ transkrypcji pinyin, obecnie oficjalnej transkrypcji języka mandaryńskiego, natomiast inne są zapisane w dosyć nietypowy sposób. Przykładem może być imię jednego z cesarzy dynastii Qing, w książce zapisane jako „Yunchzhen” natomiast w języku polskim znanym jako „Yongzheng” (z chińskiego: 雍正 帝, pinyin: Yōngzhèng Dì, tłum. Cesarz Yongzheng) (s. 26). Na dodatek, w dalszej części publikacji (s. 37) imię tego cesarza zostało zapisane już zgodnie z przyjętą transkrypcją. Zakładam, iż tłumacz oryginalnego dzieła z języka chińskiego na język rosyjski wykorzystał w swojej pracy system Palladiusza, a więc rosyjską transkrypcję sinologiczną. W trakcie aktu tłumaczenia na język polski przetłumaczone zostały litery cyrylicy oddające chińskie nazwy, a nie fonetyczne odpowiedniki tych nazw. Niestety bez znajomości zarówno języka chińskiego, jak i rosyjskiego trudno z całą pewnością stwierdzić, że niestandardowy zapis wynika z nawarstwionych niedociągnięć powstałych podczas tłumaczenia. Jednakże warto zaznaczyć, że właśnie brak konsekwencji przy transkrypcji powoduje, iż publikacja traci na swoim naukowym znaczeniu, gdyż wykorzystane w niej nazwy nie korespondują z tymi powszechnie używanymi w innych opracowaniach dotyczących Chin.

Publikacja niestety nie ustrzegła się również od literówek, na dodatek w nazwach własnych, które i tak już są wystarczająco mylące. I tak na przykład, tytułowe Zakazane Miasto, znane obecnie pod nazwą „Gugong” (z chińskiego: 故宫, pinyin: Gùgōng, tłum: Były Pałac/Starożytny Pałac) na stronie 63 dwukrotnie zostało nazwane „Gogung”. Brak również konsekwencji w stylu zapisu, na stronie 55 „Gugong” zapisane jest jako „Gu Gong”, mimo iż w całej publikacji wykorzystywany jest zapis łączny. Nie są to jedyne błędy, jednak celem recenzji nie jest wymienienie ich wszystkich.

Książka będąca przedmiotem niniejszej recenzji jest ciekawą pozycją przybliżającą polskiemu czytelnikowi historię Zakazanego Miasta w Pekinie. Na pewno będzie przydatna dla osób, które oprócz chęci zwiedzenia byłego Pałacu Cesarskiego będą miały ochotę zrozumieć jego kontekst historyczny oraz kulturowy. Niestety z powodu braku konsekwencji w transkrypcji 
chińskich nazw, odnalezienie niektórych punktów na mapie muzeum lub próba zgłębienia biografii osób związanych z tym miejscem może okazać się niemożliwa. W chwili obecnej Historia Zakazanego Miasta może być traktowana jedynie jako popularnonaukowy przewodnik, a nie wiem czy taki był cel wydawnictwa. Publikacja wymaga szczegółowej korekty pod względem nazewnictwa chińskiego, które jest kwintesencją przekazu tej książki.

MGR MONIKA PALISZEWSKA-MOJSIUK

Wydział Zarządzania

Uniwersytet Gdański

ul. Armii Krajowej 101, 81-824 Sopot

Instytut Konfucjusza przy Uniwersytecie Gdańskim

monika.paliszewska@ug.edu.pl

\section{Bibliografia}

Hejun, Feng (2017). Historia Zakazanego Miasta. Toruń: Time Marszałek Group. 